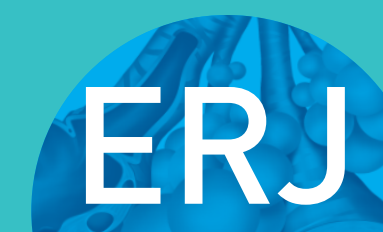

open research
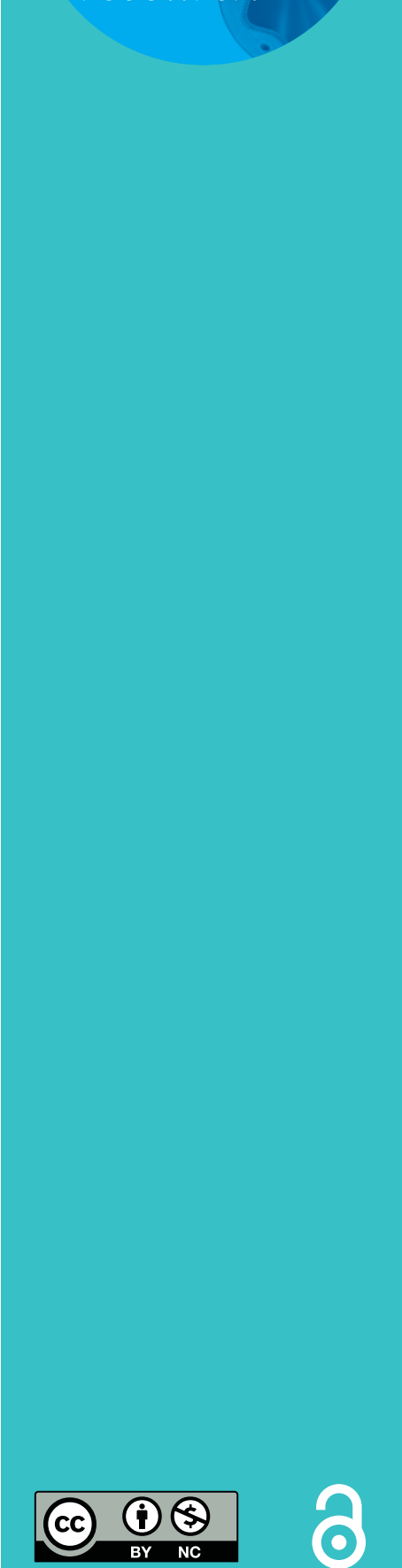

\section{Exposure assessment in hypersensitivity pneumonitis: a comprehensive review and proposed screening questionnaire}

\author{
Tananchai Petnak ${ }^{1}$ and Teng Moua ${ }^{2}$
}

Affiliations: ${ }^{1}$ Division of Pulmonary and Critical Care Medicine, Faculty of Medicine Ramathibodi Hospital, Mahidol University, Bangkok, Thailand. ${ }^{2}$ Division of Pulmonary and Critical Care Medicine, Mayo Clinic, Rochester, MN, USA.

Correspondence: Teng Moua, Division of Pulmonary and Critical Care Medicine, Mayo Clinic, 200 First St SW, Rochester, MN 55905, USA. E-mail: Moua.tenglamayo.edu

ABSTRACT Hypersensitivity pneumonitis is an immune-mediated inflammatory lung disease characterised by the inhalation of environmental antigens leading to acute and chronic lung injury. Along with suggestive clinical and radiological findings, history and timing of suspected antigen exposure are important elements for diagnostic confidence. Unfortunately, many diagnoses remain tentative and based on vague and imprecise environmental or material exposure histories. To date, there has not been a comprehensive report highlighting the frequency and type of environmental exposure that might lead to or support a more systematic approach to antigen identification. We performed a comprehensive literature review to identify and classify causative antigens and their associated environmental contexts or source materials, with emphasis on the extent of the supportive literature for each exposure type. Eligible publications were those that reported unique inciting antigens and their respective environments or contexts. A clinical questionnaire was then proposed based on this review to better support diagnosis of hypersensitivity pneumonitis when antigen testing or other clinical and radiological variables are inconclusive or incomplete.

@ERSpublications

Exposure history in hypersensitivity pneumonitis may be thought of in terms of an inciting antigen or its exposure setting or source. An approach reflecting a comprehensive assessment of the published literature may improve diagnosis and management. https://bit.ly/2AJp5vr

Cite this article as: Petnak T, Moua T. Exposure assessment in hypersensitivity pneumonitis: a comprehensive review and proposed screening questionnaire. ERJ Open Res 2020; 6: 00230-2020 [https://doi.org/10.1183/23120541.00230-2020].

This article has supplementary material available from openres.ersjournals.com.

Received: 29 April 2020 | Accepted after revision: 10 June 2020

Copyright $\odot$ ERS 2020. This article is open access and distributed under the terms of the Creative Commons Attribution Non-Commercial Licence 4.0. 


\section{Introduction}

Hypersensitivity pneumonitis (HP), also known as extrinsic allergic alveolitis, is an immune-mediated inflammatory lung disease characterised by injury from the inhalation of mostly organic environmental antigens. Multidisciplinary discussion (MDD) of relevant exposure history, suggestive radiological findings and histopathology, when available, may be helpful in making a confident diagnosis, though there remains significant equipoise even among MDD-discussed cases $[1,2]$. This may be due to overlapping findings as well as unclear and difficult to attain exposure history. For example, some occupational exposures that may increase risk of $\mathrm{HP}$, including farming or hairdressing, have also been reported as epidemiologically associated with idiopathic pulmonary fibrosis (IPF) [3]. Regarding radiological findings, a fibrotic usual interstitial pneumonia (UIP) pattern on computed tomography (CT) may be suggestive of IPF in the absence of diagnosable secondary aetiologies, but a similar pattern may be found in approximately $10 \%$ of patients with biopsy-proven fibrotic HP [4]. Moreover, $40 \%$ of patients with IPF may have features of air trapping or mosaicism on CT imaging, which may also overlap with HP [5]. Serum-precipitating antibodies against specific antigens are often obtained and may suggest HP. However, sensitivity and specificity vary widely among screening studies and have not been established in terms of clinical utility. Positive precipitating antibodies have ranged between $39-78 \%$ of patients with interstitial findings [6-10], but have also been found in those without clinical or radiological disease. Among sausage industry workers for example, 37\% may have positive precipitating antibodies, but no evidence of lung disease [11].

Given clinical overlap with other interstitial lung diseases (ILDs) and nonspecific findings on presentation, exposure history remains an important element for supporting HP diagnosis. Unfortunately, inadequate review of exposures or possible settings and materials may be a cause of frequent HP misdiagnosis [12]. There are currently more than 200 antigens reported as possible causative exposures. To the best of our knowledge, there have been few comprehensive assessments of the recent literature highlighting the specific array or frequency of environmental or occupational exposures and their inciting antigens, with the intent of generating a more concise or evidence-based review of systems or questionnaire for history-taking. Herein, we performed a literature review using Embase and Ovid/MEDLINE databases to identify and classify causative antigens and highlight the frequency and extent of supporting evidence for each exposure type.

\section{Search strategy and literature review}

We searched for publications in Embase and Ovid/MEDLINE database from November 1, 1999 to October 31, 2019, using the search terms "hypersensitivity pneumonitis" and "extrinsic allergic alveolitis". Eligible articles included clinical studies or case reports that described specific causative organisms or antigens through species-specific precipitating antibodies, positive inhalation provocation testing or lymphocyte proliferation testing. These were then reviewed for a description of the relevant or suspected environmental or occupational exposure history. Non-English-language articles, basic science or experimental animal studies and paediatric articles (age $<18$ years old) were excluded. References of included articles were also reviewed.

The search terms "hypersensitivity pneumonitis" and "extrinsic allergic alveolitis" yielded 5084 and 2062 articles, respectively. After exclusion based on language, article type and removal of duplicates, 1574 articles were screened. Of these, 1397 publications were excluded due to nonreporting or missing descriptions of suspected species-specific causative organisms or antigens. Final publications included 57 clinical studies and 120 case reports (figure 1).

\section{Type of exposure}

The included articles from this literature review identified 1596 cases with referenced antigen-positive testing (some patients were positive for more than one antigen). Negative antibody testing was reported in 427 patients but those with suspected exposures were still considered relevant HP diagnoses. Avian, fungal, bacterial, mycobacterial and other organic/inorganic exposures were identified, as described in tables 1 and 2.

\section{Animal protein exposure}

Bird or avian protein exposure was the most commonly reported form of HP, namely "bird fancier's" or "pigeon breeder's" disease. Repeated inhalation of avian proteins through bird droppings or feathers precipitated the majority of lung injury. We identified 31 publications providing specific antibody or precipitation testing against avian antigens. Most reported cases were exposed through keeping birds as pets in the home or breeding them as hobbies or professions. Goose or duck feather and down-containing duvets, pillows, coats or jackets were also a significant source of environmental exposure when there was no reported history of live bird exposure [13-19]. Notably, suspected HP cases related directly to domestic chicken or turkey exposure have not been reported or published, despite their relative ubiquity. 


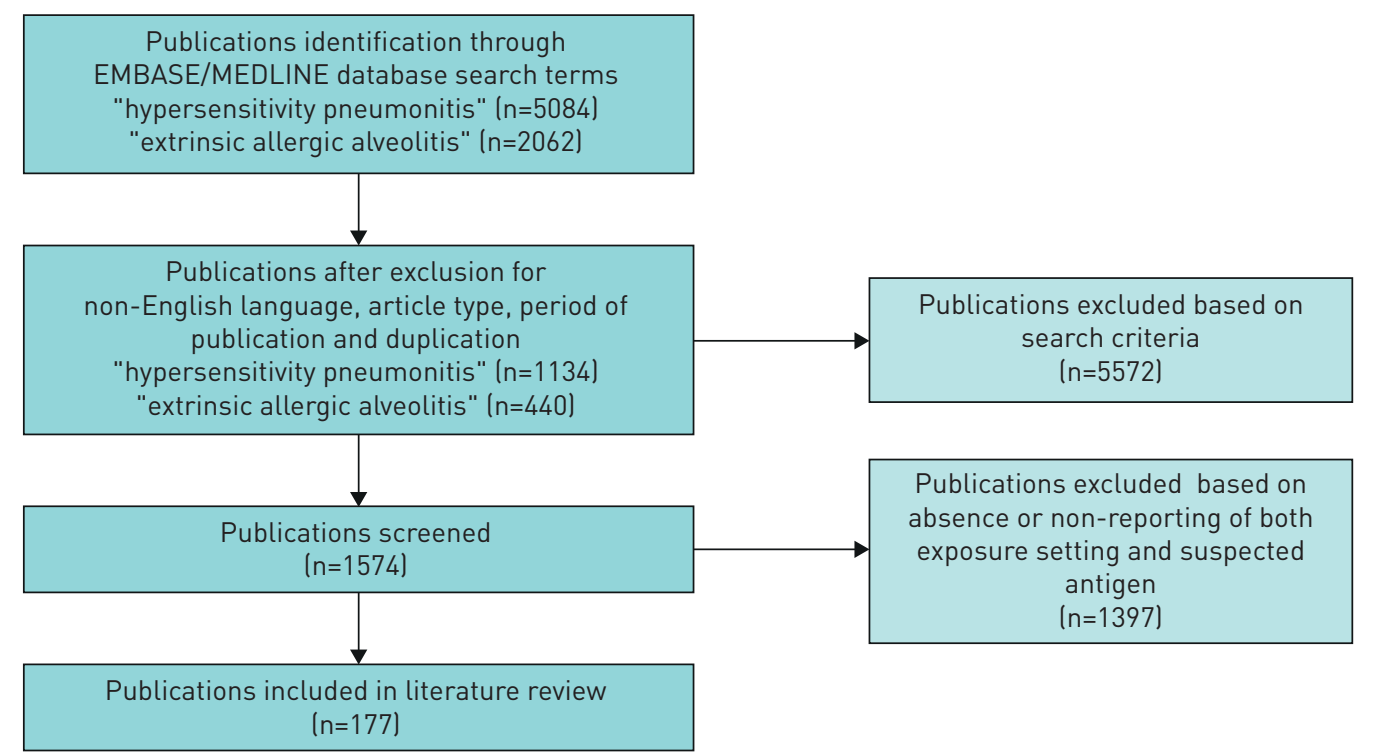

FIGURE 1 Literature search strategy.

Indirect exposure to avian antigens has also been reported. Three patients developed lung disease despite never having had direct bird exposure as a result of existing antigens in their homes from previous bird owners [20-22]. In another case, a mushroom worker developed suspected bird-related HP due to exposure to work-related poultry manure [23]. Given the high number of published HP cases and possible exposure settings, enquiring about direct and indirect exposure to bird protein through bird ownership or breeding, down or feather-containing items and droppings or faeces, is of high relevance and yield.

HP has been reported with protein exposure to two other animal species, chinchillas and flour mites. Recurrent episodes of HP in a French farmer were confirmed by positive testing for precipitating antibodies to chinchilla fur [24]. Removal of the chinchilla resulted in clinical improvement. Flour mite antigens were believed to have precipitated HP in a French baker [25].

\section{Fungal exposure}

Fungi are found in nearly every environment and are a second leading reported cause of HP. Environments or materials with water damage or moisture often support increased fungal growth and

\section{TABLE 1 Specific antigens by type}

\begin{tabular}{|c|c|c|c|c|}
\hline Type of antigens & Specific antigens & & & \\
\hline 2. Fungi & Trichosporon spp. & Aspergillus spp. & Penicillium spp. & Wallemia sebi \\
\hline & Cryptococcus spp. & Candida spp. & Rhizopus spp. & Chrysonilia sitophila \\
\hline & Absidia corymbifera & Mucor spp. & Scopulariopsis spp. & Paecilomyces spp. \\
\hline & Alternaria spp. & Aureobasidium pullulans & Cephalosporium acremonium & Neurospora crassa \\
\hline & Sphaerotheca fuliginea & Ulocladium botrytis & & \\
\hline 3. Bacteria & Thermoactinomyces spp. & Saccharopolyspora rectivirgula & Saccharomonospora viridis & Bacillus spp. \\
\hline & Streptomyces spp. & Acinitobacter spp. & Pseudomonas spp. & Stenotrophomonas spp. \\
\hline & Ochrobactrum spp. & Staphylococcus spp. & Arthrobacter spp. & Paenibacillus spp. \\
\hline & Brevibacterium spp. & Sphingobacterium spiritivorum & Enterobacter spp. & Rhanella spp. \\
\hline 4. Mycobacteria & Mycobacterium avium complex & M. immunogenum & M. chelonae & M. fortuitum \\
\hline & Catechin & Phytase & Proteolytic enzyme & Tiger nut \\
\hline
\end{tabular}


TABLE 2 Epidemiology of specific antigens by frequency of reported cases

\begin{tabular}{|c|c|c|c|c|}
\hline Specific antigens & $\begin{array}{c}\text { Number of } \\
\text { patients }\end{array}$ & $\begin{array}{l}\text { Number of unique } \\
\text { publications }\end{array}$ & Setting & $\begin{array}{l}\text { Selected } \\
\text { references }\end{array}$ \\
\hline \multirow[t]{4}{*}{ 1. Avian exposure } & 381 & 31 & & \\
\hline & 111 & 7 & Use of duck or goose down jackets, duvets or pillows & [13-19] \\
\hline & 77 & 4 & Direct contact with birds in the environment & [14] \\
\hline & 3 & 3 & Indirect contact with bird-contaminated items or environment & {$[20-22]$} \\
\hline 2. Trichosporon spp. & 145 & 15 & & \\
\hline T. asahii & 140 & 14 & Summer-type HP, domestic fungal contamination & {$[100-102]$} \\
\hline T. mucoides & 2 & 1 & Summer-type HP & {$[102]$} \\
\hline T. japonicum & 1 & 1 & Domestic fungal contamination & [103] \\
\hline Trichosporon spp. & 2 & 1 & Farm environment & {$[42]$} \\
\hline $\begin{array}{l}\text { 3. Thermoactinomyces } \\
\text { spp. }\end{array}$ & 113 & 10 & & \\
\hline 4. Aspergillus spp. & 109 & 32 & & \\
\hline A. fumigatus & 21 & 8 & $\begin{array}{l}\text { Cork factory, esparto grass, corn, bark mulch, garbage } \\
\text { exposure, domestic fungal contamination }\end{array}$ & $\begin{array}{l}{[21,28,39,52,60} \\
\quad 61,104]\end{array}$ \\
\hline A. niger & 11 & 5 & Domestic fungal contamination, onion & {$[28,40]$} \\
\hline A. flavus & 2 & 2 & Domestic fungal contamination & [28] \\
\hline A. oryzae & 1 & 1 & Koji brewer & [106] \\
\hline A. versicolor & 1 & 1 & Domestic fungal contamination & [21] \\
\hline Aspergillus spp. & 73 & 20 & $\begin{array}{l}\text { Farm environment, domestic fungal contamination, dry } \\
\text { sausage dust, metalwork fluid, dug wells, salami, flour, } \\
\text { endogenous exposure from aspergilloma, nosocomial } \\
\text { exposure, feed store and compost production }\end{array}$ & $\begin{array}{r}{[25,27,42,49,50} \\
58,95,107-112]\end{array}$ \\
\hline $\begin{array}{l}\text { 5. Saccharopolyspora } \\
\text { rectivirgula }\end{array}$ & 92 & 12 & $\begin{array}{l}\text { Farm environment, esparto grass, garbage worker, } \\
\text { summer-type HP }\end{array}$ & $\begin{array}{l}{[42,44,45,61} \\
104,113]\end{array}$ \\
\hline M. gordonae & 1 & 1 & Home humidifier & [114] \\
\hline 7. Penicillium spp. & 58 & 17 & & \\
\hline$P$. frequentans & 12 & 2 & Cork factory, mushroom worker & {$[47,52]$} \\
\hline P. glabrum & 9 & 1 & Cork factory & {$[51]$} \\
\hline P. citrinum & 6 & 2 & Mushroom worker & {$[46,115]$} \\
\hline P. chrysogenum & 2 & 1 & Garbage exposure & {$[104]$} \\
\hline P. camemberti & 1 & 1 & Salami production & {$[116]$} \\
\hline P. notatum & 1 & 1 & Corn & [39] \\
\hline Penicillium spp. & 27 & 9 & $\begin{array}{l}\text { Farm environment, dry sausage dust, metalwork fluid, onion } \\
\text { and potato processing, salami production, feed store, } \\
\text { domestic fungal contamination }\end{array}$ & $\begin{array}{l}{[41,42,49,50,95} \\
112,117]\end{array}$ \\
\hline 8. Wallemia sebi & 46 & 5 & Farm environment & {$[43-45,48]$} \\
\hline 9. Mushroom spores & 36 & 5 & Mushroom workers: Bunashimeji, Shimeji, Shitake, Eryngi & $\begin{array}{l}{[79,80,84,94} \\
118]\end{array}$ \\
\hline $\begin{array}{l}\text { 10. Eurotium } \\
\text { amstelodami }\end{array}$ & 29 & 4 & Farm environment & [43-45] \\
\hline 11. Fusarium spp. & 24 & 10 & & \\
\hline F. oxysporum & 9 & 1 & Farm environment & [45] \\
\hline F. vasinfectum & 8 & 3 & Domestic fungal contamination & {$[26,29,31]$} \\
\hline F. solani & 2 & 2 & Metalwork fluid, onion and potato processing & {$[41,70]$} \\
\hline F. napiforme & 1 & 1 & Domestic fungal contamination & [30] \\
\hline Fusarium spp. & 4 & 3 & Metalwork fluid, bassoon musical instrument & {$[57,71]$} \\
\hline
\end{tabular}




\section{TABLE 2 Continued}

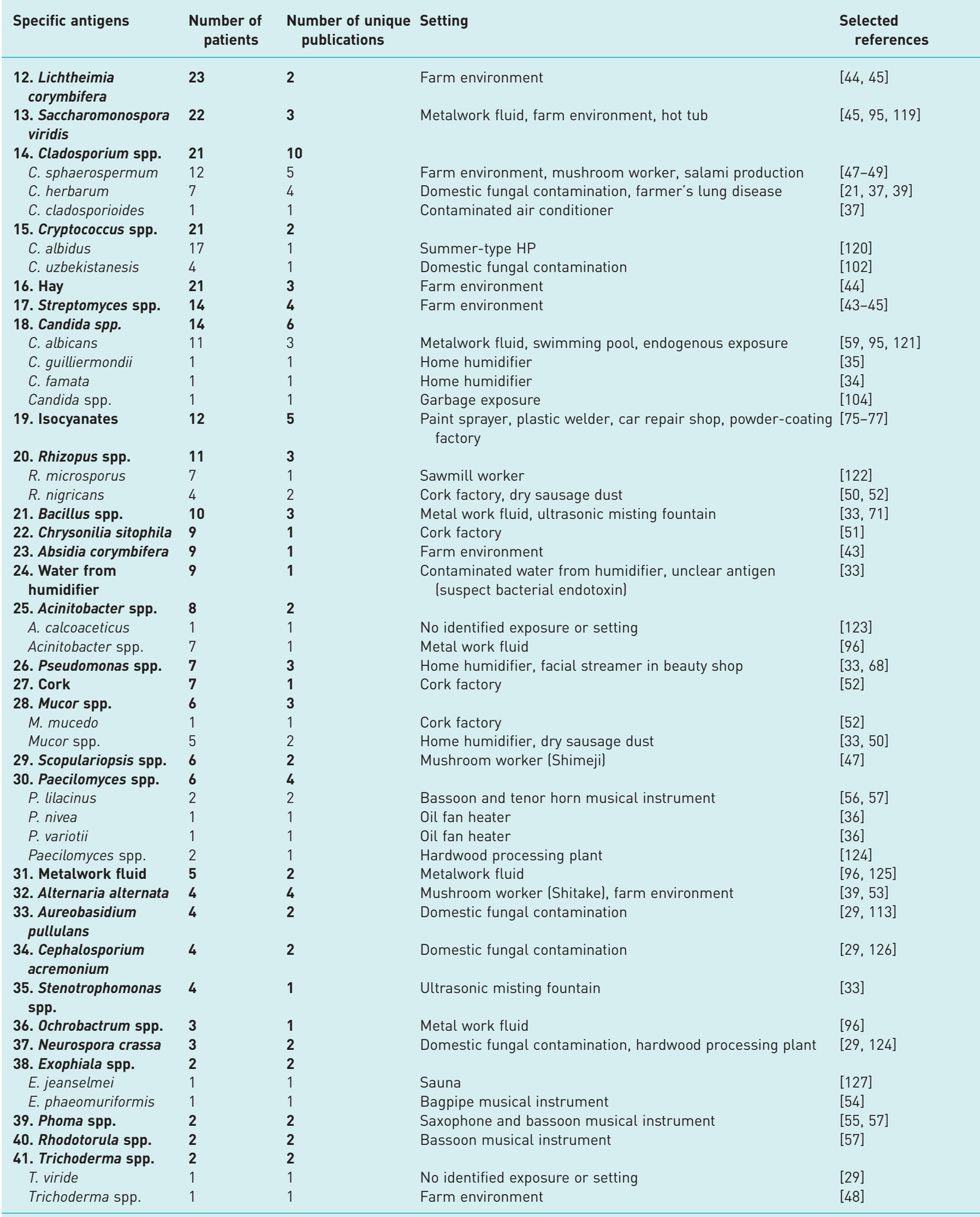




\section{TABLE 2 Continued}

\begin{tabular}{|c|c|c|c|c|}
\hline Specific antigens & $\begin{array}{c}\text { Number of } \\
\text { patients }\end{array}$ & $\begin{array}{l}\text { Number of unique } \\
\text { publications }\end{array}$ & Setting & $\begin{array}{l}\text { Selected } \\
\text { references }\end{array}$ \\
\hline 42. Corn, oat & 2 & 2 & Exposure to corn, bakery setting & {$[25,39]$} \\
\hline 44. Wheat/flour & 2 & 2 & Exposure to wheat/flour & [126] \\
\hline 45. Argan & 2 & 1 & Cosmetic factory & [128] \\
\hline 48. Flour mite & 1 & 1 & Bakery setting & [25] \\
\hline 49. Proteolytic enzyme & 1 & 1 & Surgical instrument cleaning & {$[131]$} \\
\hline 50. Tiger nut & 1 & 1 & Horchata production factory & [132] \\
\hline 51. Konjak flour & 1 & 1 & Konnyaku production factory & {$[86]$} \\
\hline 52. Phytase & 1 & 1 & Cattle feed factory & [133] \\
\hline 53. Chinchilla & 1 & 1 & Pet chinchilla & [24] \\
\hline Sphaerotheca fuliginea & 1 & 1 & Greenhouse & {$[126]$} \\
\hline Pantoea agglomerans & 1 & 1 & Herbal factory & {$[135]$} \\
\hline Ulocladium botrytis & 1 & 1 & Saxophone musical instrument & {$[55]$} \\
\hline Humicola fuscoatra & 1 & 1 & Domestic fungal contamination & {$[136]$} \\
\hline Bjerkandera adusta & 1 & 1 & Domestic fungal contamination & [137] \\
\hline Peziza domiciliana & 1 & 1 & Domestic fungal contamination & [32] \\
\hline \multicolumn{5}{|l|}{ 57. No identified setting } \\
\hline
\end{tabular}

therefore increased risk of antigen exposure. We identified 82 publications with 568 antigen-positive tests. Approximately 30 species of fungi have been reported as causative agents, described in tables 1 and 2. Trichosporon asahii is the most common in terms of number of reported cases, presenting as summer-type $\mathrm{HP}$ in Japan, followed by cases involving Aspergillus, Penicillium, Wallemia sebi and Eurotium amstelodami, in descending order, respectively.

T. asahii was found in the homes of affected patients with prior water damage and wood decay or in the trapped moisture of straw mats. T. asahii spores are often released more intensely in the summer months, causing seasonal outbreaks and the descriptive diagnosis of "summer-type HP". Outside of Japan, a variety of other fungal species have been reported in contaminated homes, including more commonly Aspergillus and Fusarium from Europe and North America, followed by Penicillium, Cladosporium, Cryptococcus, Aureobasidium pullulans, Peziza domiciliana and Cephalosporium acremonium [21, 26-32]. Fungal contamination may also occur through a variety of moisture containing or trapping domestic items, including humidifiers, air purifiers, heating units, air conditioners and ventilation ducts [33-37].

The farm environment is a commonly reported setting for both fungal and bacterial antigen exposure, resulting in so-called "farmer's lung". Both types of organism may be found in moist hay or straw, grain bins, animal feed, silage and manure, as well as on contaminated crops such as onion, potato and corn [38-41]. Reported causative fungal organisms have included W. sebi, Aspergillus, E. amstelodami, Penicillium, Lichtheimia corymbifera, Fusarium, Absidia corymbifera, Cladosporium, Alternaria alternata and Trichosporon, in decreasing frequency [39, 42-48].

Sites of food production have also been reported as sources of fungal antigen exposure, particularly in Europe. Aspergillus and Penicillium were reported as fungal contaminants in salami and dry sausage dust, leading to HP. Additional reported species include Rhizopus, Mucor and Cladosporium from salami production $[49,50]$. Other work environments that reported potential fungal contaminants include cork factories, mushroom farms and sawmills. Cork material has been reported as contaminated with 
Aspergillus, Penicillium, Rhizopus and Mucor, leading to a specific type of HP termed "suberosis" [51, 52]. Mushroom farms have also been the setting for HP, with reported precipitating antigens related to Penicillium, Cladosporium, Scopulariopsis and A. alternata [46, 47, 53].

Wind and brass musical instruments have recently been reported as associated with inciting fungal antigens. Identified species, taken specifically from a bagpipe, bassoon, saxophone and tenor horn, have included Fusarium, Paecilomyces, Exophiala phaeomuriformis, Phoma species, Purpureocillium lilacinum and Ulocladium botrytis [54-57].

Finally, endogenous antigens associated with clinical infection may also induce HP. Үознімото et al. [58] reported a case of HP precipitated by Aspergillus from an infectious aspergilloma, while SCHREIBER et al. [59] described a case of HP caused by endogenous Candida albicans.

\section{Bacterial and nontuberculous mycobacterial exposure}

Bacteria and nontuberculous mycobacteria (NTM) as inciting agents of HP have been reported less commonly compared to fungal antigens. We identified 46 publications reporting 353 antigen-positive tests. The most commonly reported environmental exposure was farm or grain dust, with two thermophilic filamentous and spore-forming bacteria Thermoactinomyces vulgaris and Saccharopolyspora rectivirgula being the most common. Although both have been found in multiple locations on farms, they have also been isolated from esparto grass or esparto fibre, a type of material used in the production of ropes and canvas $[60,61]$.

Water reservoirs have been reported as contaminated with bacteria believed to be associated with HP. Bacillus, Pseudomonas, Stenotrophomonas and Sphingobacterium spiritivorum species have been isolated from mist fountains and steam irons as possible HP antigens [33, 62]. Moreover, bacterial endotoxin itself, as detected in high levels of used wastewater, has also been proposed as possibly leading to hypersensitivity lung injury [33].

NTM mycobacteria, particularly Mycobacterium avium complex (MAC) have been reported as inciting antigens in a particular type of inflammatory lung disease known as "hot-tub lung", which some have proposed is a form of HP [63-65]. MAC isolated from either sputum or the bronchoalveolar lavage of those affected were the same genotypic species isolated from culprit hot tubs or showers [63, 66, 67]. Other NTM species, including M. fortuitum and M. mucogenicum have been reported in hot-tub lung [68, 69]. Mycobacterium in metalwork fluid, used in machine operation for automobile and aircraft manufacturing have been reported as culprit antigens for HP. M. immunogenum has been widely found and believed to cause a specific type of HP known as "machine operator's lung" [70, 71].

\section{Organic and inorganic material exposure}

Organic and inorganic chemical compounds have been reported as causative antigens in HP, including isocyanates, acid anhydrides, chloroethylenes and acrylate compounds [72-77]. We identified 39 reports with 123 antigen-positive tests. Again, reported methods used to identify specific antigens included direct measurement of precipitating circulating antibodies, inhalational challenge and lymphocyte stimulation, using samples taken directly from suspected environmental sources (mushroom, hay, corn and metalwork fluid) [78-80].

Other rare or uncommon sources of exposure leading to HP are further highlighted. Mushroom spores were the most commonly reported organic antigen causing HP outside of other fungal and bacterial species $[47,79,80]$. Precipitating antibodies against hay have also been reported [44]. Isocyanates are the only cited chemical compound with positive IgG antibody testing supporting an HP-like response [75-77, 81]. Diisocyanate, the most common form of isocyanate, is found in plastic or foam material often exposed to during manufacturing. Commercial paint and varnishes, which often involve the use of sprayers for aerosolised exposure, also contain diisocyanates and are commonly found in automobile manufacturing and repair garages [82]. Intravesicular Bacilli Calmette-Guérin (BCG) therapy for bladder cancer was reported as precipitating HP in one case study, with specific IgG against BCG confirmed by precipitating antibody testing [83]. Antibodies against extracted hay antigen, sausage dust and cork have also been reported in patients with HP. However, for these specific antigens, it may be difficult to exclude other undetected contaminating organisms (mould or bacteria) as the more clinically relevant antigen $[44,50,52]$. Other rare but reported organic and inorganic compounds include corn, oat, argan tree plant oil found in many cosmetic products, catechin phenol compounds found in green tea, pine sawdust and proteolytic enzymes used in the cleaning of surgical instruments. Tiger nut from horchata factories, Konjak flour from a Konnyaku factory, phytase used in cattle feed and shrimp shell powder found in seafood processing are additional rare but reported inciting antigens (see table 2). 
Hypersensitivity pneumonitis according to region

Epidemiology of HP may vary depending on climate, geographic conditions, availability of culprit environments and occupational or industrial practices (see supplemental tables 1-3). We classified reports into four main geographical groups according to the frequency of publication. These were Europe, East Asia (dominated by Japan), North America and a conglomerate of "others". Sixty-eight publications represented European locations followed by 59 reports from Japan, North America (40 publications) and other combined regions (10 publications). Publications from those designated as combined or "other" regions included reports from India, Mexico, South Korea, Taiwan and New Zealand. Highlighting specific exposures according to geography may be helpful in delineating patterns of presentation, though publication bias is likely based on the availability of local academic or clinical institutions able to track them. In that regard, a lack of specific reports for a region does not necessarily reflect the absence of that type of exposure or disease but perhaps more the absence of review and reporting.

Bird-related HP was the most common type of published HP in Europe and North America. Although summer-type HP was the most common type in Japan, bird-related HP was also commonly reported. However, the type of exposure or setting appeared to differ according to the described region. Bird antigen exposure with the use of down or feather-containing products appeared to be less reported in Europe compared to Japan and North America, as described in supplemental tables 1-3.

In Europe, the farm environment, metalwork fluid exposure, cork manufacturing, salami and sausage production, esparto grass and musical instruments were frequently reported as occupation or hobby-related exposure types. Although home-related HP cases were noted, they were reported less frequently than occupation-related sources of exposure.

In Japan, domestic antigen exposure was the most commonly published type of HP (summer-type HP), followed by bird-related and other occupational exposures. Japan also had the highest number of publications regarding mushroom worker's lung disease, including several specific species bunashimeji, shimeji, shitake, enoki and eryngi [46, 53, 79, 80, 84]. Unique industries in Japan, such as green tea and Konnyaku manufacturing, might suggest geographically specific work exposures for HP [85, 86].

In North America, hot-tub lung diseases associated with NTM was the most commonly reported type of HP. HP related to metalwork fluid was also common. Home-related HP associated with water damage or mould-contaminated homes was the next most commonly reported subtype, followed by HP related to the farm environment [87], with a lower number of identifiable causative antigens.

\section{A proposed screening questionnaire for HP exposure}

Previous reports suggest that HP may be underdiagnosed or misdiagnosed due to failure or inability to identify causative exposures $[1,12,29,78]$. A large report from the United States suggested that nearly $40 \%$ of patients with suspected HP did not have an identifiable antigen or exposure setting [87]. Antigen identification may also be associated with prognosis [88], where suspected exposure identification and removal of the offending antigen may play a key role in management. Currently, there is no widely accepted review based on comprehensive or systemic reporting from the literature to guide screening for suspected exposures in patients presenting with parenchymal lung disease. VASAKOVA et al. [1] recently proposed a questionnaire to screen for all causes of ILD, which included common HP exposures, but was not specific to HP. For general use, we proposed a comprehensive screening questionnaire to cover the majority of specific antigens and their culprit exposures as reported in our literature review (table 3).

\section{Discussion}

Antigen exposure history is important in the diagnosis and management of HP, as presenting clinical and radiological findings may be fleeting or overlap with other ILD and be challenging to diagnose. In the absence of widely accepted diagnostic criteria, particularly for fibrotic HP cases, a balance of contributing factors appears to increase diagnostic confidence.

Relevant exposure history for many clinicians is a leading factor in suspected diagnosis, though may prove difficult to accurately assess, exclude or confirm. When present it may support HP diagnosis even when clinical, radiological or serological findings are equivocal, but be absent when the latter is strongly suggestive and cast doubt on the suspected diagnosis. The degree to which exposure history is convincing one way or another may also be dependent on the presenting stage or subtype of HP. For example, in some cases of acute or subacute HP with typical or suggestive radiological findings, a relevant and timely exposure history may be sufficient to make a diagnosis without additional serological or histopathological testing. In contrast, patients presenting with UIP-like radiological features (traction bronchiectasis with honeycombing) might strongly suggest IPF unless a particularly strong and solicited exposure history is noted [89]. Solicited exposure history may also be considered inconclusive or incidental if the overriding 
TABLE 3 Evidence-based exposure screening questionnaire

$\begin{array}{cc}\text { Number of } & \text { Number of } \\ \text { published cases } & \text { publications }\end{array}$

1. Have you been exposed to birds or feather/down-containing items?

$\square$ YES $\square$ NO Bird: Pet birds (tropical), pigeon breeding or other birds in your environment? (duck and geese)

$\square$ YES $\square$ NO Feather/down-containing items (duck or goose down-containing jackets, pillows, blankets or feather dusters)?

$\square$ YES $\square$ Noxposure to bird droppings in a farm, factory, or home setting (droppings in an attic, barn, porch or yard)?

2. Have you had any of the following in your home or work environment?

$\begin{array}{lll}\square \text { YES } & \square \text { NO } & \text { Humidifiers or mist fountains } \\ \square \text { YES } & \square \text { NO } & \text { Mould or mildew } \\ \square \text { YES } & \square \text { NO } & \text { Moist or decayed wood } \\ \square \text { YES } & \square \text { NO } & \text { Flood/water damage } \\ \square \text { YES } & \square \text { NO } & \text { Straw mats } \\ \square \text { YES } & \square \text { NO } & \text { Window or single unit air conditioners } \\ \square \text { YES } & \square \text { NO } & \text { Oil fan heater } \\ \square \text { YES } & \square \text { NO } & \text { Steam iron }\end{array}$

3. Do you frequently use a hot tub, jacuzzi or sauna?

$\square$ YES $\square$ NO

4. Have you had any of the following occupations or hobbies or worked in any of the following locations?

$\begin{array}{lll}\square \text { YES } & \square \text { NO } & \text { Farm/greenhouse worker } \\ \square \text { YES } & \square \text { NO } & \text { Machine operator } \\ \square \text { YES } & \square \text { NO } & \text { Mushroom worker or worker in mushroom factories } \\ \square \text { YES } & \square \text { NO } & \text { Carpenter/sawmill worker or worked in a hardwood processing plant } \\ \square \text { YES } & \square \text { NO } & \text { Wind or brass musical instrument le.g. saxophone, bassoon, tenor horn, bagpipe) } \\ \square \text { YES } & \square \text { NO } & \text { Painter or paint sprayer } \\ \square \text { YES } & \square \text { NO } & \text { Garbage collector } \\ \square \text { YES } & \square \text { NO } & \text { Well digger } \\ \square \text { YES } & \square \text { NO } & \text { Baker } \\ \square \text { YES } & \square \text { NO } & \text { Working with plaster } \\ \square \text { YES } & \square \text { NO } & \text { Plastic welder } \\ \square \text { YES } & \square \text { NO } & \text { Food production or processing: salami, dry sausage, green tea, onion, potato, flour, } \\ & & \text { wheat, seafood } \\ \square \text { YES } & \square \text { NO } & \text { Cork factory } \\ \square \text { YES } & \square \text { NO } & \text { Repair garage or aircraft manufacturing } \\ \square \text { YES } & \square \text { NO } & \text { Esparto fibre factory } \\ \square \text { YES } & \square \text { NO } & \text { Cosmetic production } \\ \square \text { YES } & \square \text { NO } & \text { Warehouses } \\ \square \text { YES } & \square \text { NO } & \text { Feeding stores/factory }\end{array}$

243
111
2

17
13
9
4
2
1
1
1
58

26

5

1

17

295

$48-5$

$42 \quad 8$

$16-5$

54

52

5

1

3

1

clinical concern for IPF and its poorer prognosis is high, particularly in the absence of other supportive findings like histopathology. Clinical improvement or stability after antigen avoidance might support an HP diagnosis, though fibrotic HP cases may still progress despite suspected antigen avoidance.

In practice, exposure history may be thought of as comprising two related elements: the suspected and relevant inciting antigen (e.g. avian, mould, bacterial, mushroom spore) and its source or environmental context (e.g. occupation, farm environment, water damage, feather duvets or blankets, showerheads). Clinicians may equate the two as part of a working diagnosis; however, it is not uncommon to suspect a culprit environment or occupation without a specific antigen or vice versa (positive antibody testing for one or more antigens on screening but no identifiable exposure or occupational history). When only one or the other is present, diagnostic confidence may remain low without the support of other suggestive radiological or histopathological findings.

Additionally, environmental exposure history may be insufficient to conclude an inciting culprit antigen as multiple antigens may be involved in various settings in the same patient. A variety of methods are available as screening or directed testing to confirm specific antigen sensitivity, including the measurement of precipitating antibodies, inhalational challenge and lymphocyte proliferation [78, 90]. Confirmation of precipitating antigens using a panel of more commonly encountered mould or avian antigens may be useful when there is no apparent history of suspected exposure or more than one potential precipitating antigen 
may be involved. Identification of suspected antigens may also be critical to management as antigen avoidance can reduce further lung injury. Although unidentified antigens were reported as an independent risk factor for poorer outcome [88], the exact prognostic role of antigen identification remains controversial, with other reports suggesting opposing results, particularly in those with fibrotic disease [91-93].

Soliciting a possible environmental setting or source of known exposure may be the only available step in avoiding antigen exposure. While serologic testing might support a specific organism or antigen, such testing may not be readily available or be unable to test all possible culprit antigens. Instead, a useful review of exposures to relevant environments or materials may better assist clinicians in the efficient use of specific serological studies. For example, living on a farm is a commonly solicited but nonspecific setting that may involve exposure to avian, fungal and bacterial antigens. Additional testing to confirm hypersensitivity to relevant antigens such as T. vulgaris, S. rectivirgula, W. sebi, Aspergillus and E. amstelodami may be helpful for potentially excluding more commonly inciting antigens if negative [42-45, 94]. Otherwise, a history of farm exposure on its own may be insufficient to confirm HP diagnosis or assist in antigen avoidance. The domestic or residential environment is another example of multiple sources of possible contamination and antigen exposure in one environment. Fungal exposure may involve trapped moisture in water-damaged structures, heaters or air conditioners, with contamination of both bacteria and fungi in the water reservoirs of humidifiers and steam irons. Colonisation of mycobacteria in showerheads or hot tubs is a commonly solicited source of potential antigen exposure in the United States [33, 65]. Patients working in commercial garages might be exposed to metalwork fluid used in machine operation as well as diisocyanates found in some commercial paints $[70,76,95,96]$. Proving antigen hypersensitivity may be nearly impossible in these settings, other than to empirically avoid exposure, which for some may mean potential loss of livelihoods or property when exposure does not necessarily mean related disease.

Despite the abundance of available literature, there has been little agreement on the merit or significance of which exposures should be more specifically sought out during history-taking and which may be of less relevance. BARNES et al. [97] recently completed a Delphi assessment of 36 international experts and found agreement on 18 items for clinical review of exposures in fibrotic or chronic HP. The five with highest agreement (97\%, with inclusion cut-off of $80 \%$ ) included exposure to mouldy hay or silage, standing water, water damage or flooding, visible mould or a mouldy smell and bird or avian protein exposure. An in-depth literature review was pursued prior to the Delphi process to provide a comprehensive list of exposure items, with final suggested exposure items more or less reflecting agreement between the extent of reported cases and expert clinical experience. This is an important first step in unifying a history-taking approach, particularly in fibrotic HP, though the authors note that future studies are needed to support prospective utility.

In summary, our review suggests that bird protein exposure was the most frequently reported setting or exposure type, followed by specific exposures in the farm environment, home or domestic fungal or bacterial contamination, occupational metalwork fluid exposure and mushroom spores, respectively. However, we included a majority of studies reporting both a specific antigen and its suspected environmental setting or source, which may not be reflective of how real-world HP diagnoses are made as often one or both of these components may be missing in typically diagnosed cases. Sensitivity of serum IgG antibodies to suspected antigens in fibrotic HP has been reported as often absent or lower than in nonfibrotic or more acute cases, which might also lead to the inclusion of less fibrotic HP studies in our review [7]. In contrast, we also reviewed and included less commonly solicited or reported antigens that may be regionally or geographically differentiated or prove more incidental to specific occupations or hobbies. Rare or novel precipitating exposures, which have yet to be confirmed or supported by antigen-detecting studies such as precipitating serum antibodies or inhalational challenge testing, were not included in our review. Indeed, the use of such confirmatory or supportive antigen studies varies among institutions and is hindered by lack of standardisation. Finally, while we proposed a comprehensive screening questionnaire covering the majority of causative antigens and their culprit environments based on a systematic review of the published literature, the actual epidemiology of particular organisms and clinical validation of this or any other questionnaire requires further study and may lead to additional customisation based on institutional need, geography and population demographics.

\section{Conclusion}

In summary, identification of specific antigens and their exposure source in patients with suspected HP remains challenging. Not only is the identification of suspected antigens and their sources helpful in HP diagnosis but may also play a role in antigen avoidance, which may affect prognosis and outcome. Bird antigen exposure was the most frequently reported cause of HP from the literature, followed by fungal, bacterial and organic or inorganic antigens. After a comprehensive review of reported antigens and their 
associated exposure source, we proposed a directed questionnaire to screen for suspected exposures in patients presenting with undifferentiated parenchymal lung disease.

Conflict of interest: T. Petnak has nothing to disclose. T. Moua has nothing to disclose.

\section{References}

1 Vasakova M, Morell F, Walsh S, et al. Hypersensitivity pneumonitis: perspectives in diagnosis and management. Am J Respir Crit Care Med 2017; 196: 680-689.

2 Morisset J, Johannson KA, Jones KD, et al. Identification of diagnostic criteria for chronic hypersensitivity pneumonitis: an international modified Delphi survey. Am J Respir Crit Care Med 2018; 197: 1036-1044.

3 Baumgartner KB, Samet JM, Coultas DB, et al. Occupational and environmental risk factors for idiopathic pulmonary fibrosis: a multicenter case-control study. Collaborating Centers. Am J Epidemiol 2000; 152: 307-315.

4 Alberti ML, Malet Ruiz JM, Fernandez ME, et al. Comparative survival analysis between idiopathic pulmonary fibrosis and chronic hypersensitivity pneumonitis. Pulmonology 2020; 26: 3-9.

5 Hochhegger B, Sanches FD, Altmayer SPL, et al. Air trapping in usual interstitial pneumonia pattern at CT: prevalence and prognosis. Sci Rep 2018; 8: 17267.

6 Baqir M, White D, Ryu JH. Emphysematous changes in hypersensitivity pneumonitis: A retrospective analysis of 12 patients. Respir Med Case Rep 2018; 24: 25-29.

7 De Sadeleer LJ, Hermans F, De Dycker E, et al. Effects of corticosteroid treatment and antigen avoidance in a large hypersensitivity pneumonitis cohort: a single-centre cohort study. J Clin Med 2018; 8: 14.

8 Jacob J, Bartholmai BJ, Egashira R, et al. Chronic hypersensitivity pneumonitis: identification of key prognostic determinants using automated CT analysis. BMC Pulm Med 2017; 17: 81.

9 Lacasse Y, Selman M, Costabel U, et al. Clinical diagnosis of hypersensitivity pneumonitis. Am J Respir Crit Care Med 2003; 168: 952-958.

10 Ley B, Newton CA, Arnould I, et al. The MUC5B promoter polymorphism and telomere length in patients with chronic hypersensitivity pneumonitis: an observational cohort-control study. Lancet Respir Med 2017; 5: 639-647.

11 Rouzaud P, Soulat JM, Trela C, et al. Symptoms and serum precipitins in workers exposed to dry sausage mould: consequences of exposure to sausage mould. Int Arch Occup Environ Health 2001; 74: 371-374.

12 Selman M, Pardo A, King TE Jr. Hypersensitivity pneumonitis: insights in diagnosis and pathobiology. Am Respir Crit Care Med 2012; 186: 314-324.

13 Hanak V, Golbin JM, Ryu JH. Causes and presenting features in 85 consecutive patients with hypersensitivity pneumonitis. Mayo Clin Proc 2007; 82: 812-816.

14 Masuo M, Miyazaki Y, Suhara K, et al. Factors associated with positive inhalation provocation test results in subjects suspected of having chronic bird-related hypersensitivity pneumonitis. Respir Investig 2016; 54: 454-461.

15 Inase $\mathrm{N}$, Ohtani $\mathrm{Y}$, Sumi $\mathrm{Y}$, et al. A clinical study of hypersensitivity pneumonitis presumably caused by feather duvets. Ann Allergy Asthma Immunol 2006; 96: 98-104.

16 Jacobs MR, Andrews CP, Ramirez RM, et al. Frequency of goose and duck down causation of hypersensitivity pneumonitis within an 80-patient cohort. Ann Allergy Asthma Immunol 2019; 123: 201-207.

17 Mikumo H, Yanagihara T, Hamada N, et al. An autopsy case of bird-related chronic hypersensitivity pneumonitis presenting with repeated acute exacerbation. Respir Med Case Rep 2018; 24: 92-94.

18 Shaw J, Leonard C, Chaudhuri N. Feather bedding as a cause of hypersensitivity pneumonitis. QJM 2017; 110 233-234.

19 Inase N, Ohtani Y, Endo J, et al. Feather duvet lung. Med Sci Monit 2003; 9: CS37-CS40.

20 Merget R, Sander I, Ewig S, et al. Consort hypersensitivity pneumonitis. Eur Respir J 2009; 33: 1223-1225.

21 Sennekamp J, Morr H, Behr J. Extrinsic allergic alveolitis with IgA deficiency. Eur J Med Res 2004; 9: 573-574.

22 Greinert U, Lepp U, Becker W. Bird Keeper's lung without bird keeping. Eur J Med Res 2000; 5: 124.

23 Hayes J, Barrett M. Bird fancier's lung in mushroom workers. Ir Med J 2015; 108: 119-120.

24 Guion Dusserre M, Soumagne T, Reboux G, et al. Second hypersensitivity pneumonitis in the same patient caused by chinchillas. J Investig Allergol Clin Immunol 2018; 28: 441-442.

25 Gerfaud-Valentin M, Reboux G, Traclet J, et al. Occupational hypersensitivity pneumonitis in a baker: a new cause. Chest 2014; 145: 856-858.

26 Dickson SD, Tankersley MS. Fatal hypersensitivity pneumonitis from exposure to Fusarium vasinfectum in a home environment: a case report. Int Arch Allergy Immunol 2015; 166: 150-153.

27 Enriquez-Matas A, Quirce S, Hernandez E, et al. Hypersensitivity pneumonitis caused by domestic exposure to molds. J Investig Allergol Clin Immunol 2007; 17: 126-127.

28 Hariri LP, Mino-Kenudson M, Shea B, et al. Distinct histopathology of acute onset or abrupt exacerbation of hypersensitivity pneumonitis. Hum Pathol 2012; 43: 660-668.

29 Jacobs RL, Andrews CP, Coalson J. Organic antigen-induced interstitial lung disease: diagnosis and management. Ann Allergy Asthma Immunol 2002; 88: 30-41.

30 Lee SK, Kim SS, Nahm DH, et al. Hypersensitivity pneumonitis caused by Fusarium napiforme in a home environment. Allergy 2000; 55: 1190-1193.

31 Ramirez RM, Jacobs RL. Hypersensitivity pneumonitis by Fusarium vasinfectum in a home environment. J Allergy Clin Immunol Pract 2014; 2: 483-484.

32 Wright RS, Dyer Z, Liebhaber MI, et al. Hypersensitivity pneumonitis from Pezizia domiciliana. A case of El Nino lung. Am J Respir Crit Care Med 1999; 160: 5 Pt 1, 1758-1761.

33 Koschel D, Stark W, Karmann F, et al. Extrinsic allergic alveolitis caused by misting fountains. Respir Med 2005; 99: 943-947.

34 Yamamoto Y, Osanai S, Fujiuchi S, et al. Extrinsic allergic alveolitis induced by the yeast Debaryomyces hansenii. Eur Respir J 2002; 20: 1351-1353.

35 Ando A, Hagiya H, Nada T, et al. Hypersensitivity pneumonitis caused by a home ultrasonic humidifier contaminated with Candida guilliermondii. Intern Med 2017; 56: 3109-3112. 
Hara J, Fujimura M, Tachibana $\mathrm{H}$, et al. A case of acute hypersensitivity pneumonitis associated with an oil fan heater. Am J Med Sci 2006; 331: 35-36.

Chiba S, Okada S, Suzuki Y, et al. Cladosporium species-related hypersensitivity pneumonitis in household environments. Intern Med 2009; 48: 363-367.

Moreno-Ancillol A, Dominguez-Noche C, Gil-Adrados AC, et al. Hypersensitivity pneumonitis due to occupational inhalation of fungi-contaminated corn dust. J Investig Allergol Clin Immunol 2004; 14: 165-167.

Martin-Garcia C, Hinojosa M, Porcel S, et al. Corn-induced hypersensitivity pneumonitis. Allergy 2003; 58: 534-535.

Sakamoto T, Yamasaki A, Funaki Y, et al. An onion farmer with a case of hypersensitivity pneumonitis caused by Aspergillus niger. Respir Med Case Rep 2018; 23: 60-62.

Merget R, Sander I, Rozynek P, et al. Occupational hypersensitivity pneumonitis due to molds in an onion and potato sorter. Am J Ind Med 2008; 51: 117-119.

Cano-Jimenez E, Rubal D, Perez de Llano LA, et al. Farmer's lung disease: analysis of 75 cases. Med Clin (Barc) 2017; 149: 429-435.

Reboux G, Piarroux R, Mauny F, et al. Role of molds in farmer's lung disease in Eastern France. Am J Respir Crit Care Med 2001; 163: 1534-1539.

Roussel S, Reboux G, Rognon B, et al. Comparison of three antigenic extracts of Eurotium amstelodami in serological diagnosis of farmer's lung disease. Clin Vaccine Immunol 2010; 17: 160-167.

Soumagne T, Chardon ML, Dournes G, et al. Emphysema in active farmer's lung disease. PLoS ONE 2017; 12 e0178263.

Yoshikawa S, Tsushima K, Yasuo M, et al. Hypersensitivity pneumonitis caused by Penicillium citrinum, not Enoki spores. Am J Ind Med 2007; 50: 1010-1017.

Akizuki $\mathrm{N}$, Inase $\mathrm{N}$, Ishiwata $\mathrm{N}$, et al. Hypersensitivity pneumonitis among workers cultivating Tricholoma conglobatum (shimeji). Respiration 1999; 66: 273-278.

Soumagne T, Pana-Katatali H, Degano B, et al. Combined pulmonary fibrosis and emphysema in hypersensitivity pneumonitis. BMJ Case Rep 2015; 2015 : bcr2015211560.

Marvisi M, Balzarini L, Mancini C, et al. A new type of hypersensitivity pneumonitis: salami brusher's disease. Monaldi Arch Chest Dis 2012; 77: 35-37.

Morell F, Cruz MJ, Gomez FP, et al. Chacinero's lung - hypersensitivity pneumonitis due to dry sausage dust. Scand J Work Environ Health 2011; 37: 349-356.

Winck JC, Delgado L, Murta R, et al. Antigen characterization of major cork moulds in Suberosis (cork worker's pneumonitis) by immunoblotting. Allergy 2004; 59: 739-745.

Morell F, Roger A, Cruz MJ, et al. Suberosis: clinical study and new etiologic agents in a series of eight patients. Chest 2003; 124: 1145-1152.

Ampere A, Delhaes L, Soots J, et al. Hypersensitivity pneumonitis induced by Shiitake mushroom spores. Med Mycol 2012; 50: 654-657.

Ziegler K, Joest M, Turan N, et al. Hypersensitivity pneumonitis of a bagpipe player: fungal antigens as trigger? Med Mycol Case Rep 2019; 24: 44-47. 2010; 138: 724-726.

Davidson J, McErlane J, Aljboor K, et al. Musical instruments, fungal spores and hypersensitivity pneumonitis QJM 2019; 112: 287-289.

Moller J, Hyldgaard C, Kronborg-White SB, et al. Hypersensitivity pneumonitis among wind musicians - an overlooked disease? Eur Clin Respir J 2017; 4: 1351268.

Yoshimoto A, Ichikawa Y, Waseda Y, et al. Chronic hypersensitivity pneumonitis caused by Aspergillus complicated with pulmonary aspergilloma. Intern Med 2004; 43: 982-985.

Schreiber J, Goring HD, Rosahl W, et al. Interstitial lung disease induced by endogenous Candida albicans. Eur J Med Res 2001; 6: 71-74.

Moreno-Ancillo A, Dominguez-Noche C, Carmen Gil-Adrados A, et al. Familial presentation of occupationa hypersensitivity pneumonitis caused by Aspergillus-contaminated esparto dust. Allergol Immunopathol (Madr) 2003; 31: 294-296.

Gamboa PM, Urbaneja F, Olaizola I, et al. Specific IgG to Thermoactynomices vulgaris, Micropolyspora faeni and Aspergillus fumigatus in building workers exposed to esparto grass (plasterers) and in patients with esparto-induced hypersensitivity pneumonitis. J Investig Allergol Clin Immunol 2005; 15: 17-21.

Kampfer P, Engelhart S, Rolke M, et al. Extrinsic allergic alveolitis (hypersensitivity pneumonitis) caused by Sphingobacterium spiritivorum from the water reservoir of a steam iron. J Clin Microbiol 2005; 43: 4908-4910.

Rickman OB, Ryu JH, Fidler ME, et al. Hypersensitivity pneumonitis associated with Mycobacterium avium complex and hot tub use. Mayo Clin Proc 2002; 77: 1233-1237.

Moraga-McHaley SA, Landen M, Krapfl $\mathrm{H}$, et al. Hypersensitivity pneumonitis with Mycobacterium avium complex among spa workers. Int J Occup Environ Health 2013; 19: 55-61.

Hanak V, Kalra S, Aksamit TR, et al. Hot tub lung: presenting features and clinical course of 21 patients. Respir Med 2006; 100: 610-615.

van der Zanden RJ, Magis-Escurra C, de Lange WC, et al. Hypersensitivity pneumonitis caused by Mycobacterium avium subsp. hominissuis in a hot tub, as proven by IS1245 RFLP and rep-PCR typing. Int J Mycobacteriol 2012; 1: 152-154.

Minomo S, Tachibana K, Tsuyuguchi K, et al. A unique case of hot tub lung worsening during the winter. Intern Med 2015; 54: 491-495.

Soumagne T, Reboux G, Degano B, et al. Hypersensitivity pneumonitis in a beautician. Am J Ind Med 2016; 59: 1041-1045.

Verma G, Jamieson F, Chedore P, et al. Hot tub lung mimicking classic acute and chronic hypersensitivity pneumonitis: two case reports. Can Respir J 2007; 14: 354-356.

Tillie-Leblond I, Grenouillet F, Reboux G, et al. Hypersensitivity pneumonitis and metalworking fluids contaminated by mycobacteria. Eur Respir J 2011; 37: 640-647. 
Barrera C, Reboux G, Warfolomeow I, et al. External validation of recombinant antigens for serodiagnosis of machine operator's lung. Am I Ind Med 2014; 57: 195-201.

Kim YJ, Hwang ED, Leem AY, et al. A case of occupational hypersensitivity pneumonitis associated with trichloroethylene. Tuberc Respir Dis (Seoul) 2014; 76: 75-79.

Piirila P, Hodgson U, Estlander T, et al. Occupational respiratory hypersensitivity in dental personnel. Int Arch Occup Environ Health 2002; 75: 209-216.

Zeiss CR, Wolkonsky P, Chacon R, et al. Syndromes in workers exposed to trimellitic anhydride. A longitudinal clinical and immunologic study. Ann Intern Med 1983; 98: 8-12.

Quirce S, Fernandez-Nieto M, Gorgolas M, et al. Hypersensitivity pneumonitis caused by triglycidy isocyanurate. Allergy 2004; 59: 1128.

Schreiber J, Knolle J, Sennekamp J, et al. Sub-acute occupational hypersensitivity pneumonitis due to low-leve exposure to diisocyanates in a secretary. Eur Respir J 2008; 32: 807-811.

Sumi Y, Kyi M, Miyazaki Y, et al. Cytokine mRNA expression in isocyanate-induced hypersensitivity pneumonitis. Respiration 2003; 70: 284-291.

Nogueira R, Melo N, Novais EBH, et al. Hypersensitivity pneumonitis: antigen diversity and disease implications. Pulmonology 2019; 25: 97-108.

Tsushima K, Furuya S, Yoshikawa S, et al. Therapeutic effects for hypersensitivity pneumonitis induced by Japanese mushroom (Bunashimeji). Am J Ind Med 2006; 49: 826-835. aggregatum. Chest 2001; 120: 1085-1093.

Yoshizawa Y, Ohtani Y, Hayakawa H, et al. Chronic hypersensitivity pneumonitis in Japan: a nationwide epidemiologic survey. J Allergy Clin Immunol 1999; 103: 2 Pt 1, 315-320.

Lockey JE, Redlich CA, Streicher R, et al. Isocyanates and human health: multistakeholder information needs and research priorities. J Occup Environ Med 2015; 57: 44-51.

Um SJ, Lee SK, Yang DK. Hypersensitivity pneumonitis following intravesical bacille Calmette-Guerin immunotherapy for superficial bladder cancer. J Investig Allergol Clin Immunol 2009; 19: 230-232.

Saikai T, Tanaka H, Fuji M, et al. Hypersensitivity pneumonitis induced by the spore of Pleurotus eryngii (Eringi). Intern Med 2002; 41: 571-573.

Tanaka Y, Shirai T, Enomoto N, et al. Occupational hypersensitivity pneumonitis in a green tea manufacturer. Respirol Case Rep 2016; 4: e00152.

Tajima S, Kon H, Oshikawa K, et al. Hypersensitivity pneumonitis induced by Konjak flour and powdered Hijikia fusiforme. Intern Med 2003; 42: 846-849.

Fernandez Perez ER, Kong AM, Raimundo K, et al. Epidemiology of hypersensitivity pneumonitis among an insured population in the United States: a claims-based cohort analysis. Ann Am Thorac Soc 2018; 15: 460-469.

Fernandez Perez ER, Swigris JJ, Forssen AV, et al. Identifying an inciting antigen is associated with improved survival in patients with chronic hypersensitivity pneumonitis. Chest 2013; 144: 1644-1651.

Morell F, Villar A, Montero MA, et al. Chronic hypersensitivity pneumonitis in patients diagnosed with idiopathic pulmonary fibrosis: a prospective case-cohort study. Lancet Respir Med 2013; 1: 685-694.

Suhara K, Miyazaki Y, Okamoto T, et al. Utility of immunological tests for bird-related hypersensitivity pneumonitis. Respir Investig 2015; 53: 13-21.

Hanak V, Golbin JM, Hartman TE, et al. High-resolution CT findings of parenchymal fibrosis correlate with prognosis in hypersensitivity pneumonitis. Chest 2008; 134: 133-138.

Ojanguren I, Morell F, Ramon MA, et al. Long-term outcomes in chronic hypersensitivity pneumonitis. Allergy 2019; 74: 944-952.

Wang LJ, Cai HR, Xiao YL, et al. Clinical characteristics and outcomes of hypersensitivity pneumonitis: a population-based study in China. Chin Med J 2019; 132: 1283-1292.

Suzuki K, Tanaka H, Sugawara H, et al. Chronic hypersensitivity pneumonitis induced by Shiitake mushroom spores associated with lung cancer. Intern Med 2001; 40: 1132-1135.

Fox J, Anderson H, Moen T, et al. Metal working fluid-associated hypersensitivity pneumonitis: an outbreak investigation and case-control study. Am J Ind Med 1999; 35: 58-67.

Dawkins P, Robertson A, Robertson W, et al. An outbreak of extrinsic alveolitis at a car engine plant. Occup Med (Lond) 2006; 56: 559-565.

Barnes H, Morisset J, Molyneaux P, et al. A systematically derived exposure assessment instrument for chronic hypersensitivity pneumonitis. Chest 2020; 157: 1506-1512.

Morell F, Roger A, Reyes L, et al. Bird fancier's lung: a series of 86 patients. Medicine (Baltimore) 2008; 87: 110-130. interstitial fibrosis. Ann Allergy Asthma Immunol 2007; 99: 465-466. pneumonitis and proposition of diagnostic criteria. Respir Investig 2020; 58: 59-67. pneumonitis. Respir Investig 2015; 53: 217-224.

Unoura K, Miyazaki Y, Sumi Y, et al. Identification of fungal DNA in BALF from patients with home-related hypersensitivity pneumonitis. Respir Med 2011; 105: 1696-1703.

Hirakata Y, Katoh T, Ishii Y, et al. Trichosporon asahii-induced asthma in a family with Japanese summer-type hypersensitivity pneumonitis. Ann Allergy Asthma Immunol 2002; 88: 335-338.

Hagemeyer O, Bunger J, van Kampen V, et al. Occupational allergic respiratory diseases in garbage workers: relevance of molds and actinomycetes. Adv Exp Med Biol 2013; 788: 313-320.

Szturmowicz M, Baranska I, Jedrych ME, et al. Hypersensitivity pneumonitis recognised in a single pulmonary unit, between 2005 and 2015 - comparison with recently proposed diagnostic criteria. Adv Respir Med 2019; 87: 83-89.

Ishiguro T, Kawai S, Kojima A, et al. Occupational hypersensitivity pneumonitis in a koji brewer. Clin Case Rep 2018; 6: 461-464. 
Da Broi U, Orefice U, Cahalin C, et al. ARDS after double extrinsic exposure hypersensitivity pneumonitis Intensive Care Med 1999; 25: 755-757.

108 Higashi A, Higashi N, Tsuburai T, et al. Involvement of eicosanoids and surfactant protein D in extrinsic allergic alveolitis. Eur Respir J 2005; 26: 1069-1073.

109 Katsuya Y, Hojo M, Kawai S, et al. Chronic granulomatous disease with pulmonary mass-like opacities secondary to hypersensitivity pneumonitis: a case report. J Med Case Rep 2014; 8: 242.

110 Lal A, Akhtar J, Pinto S, et al. Recurrent pulmonary embolism and hypersensitivity pneumonitis secondary to Aspergillus, in a compost plant worker: case report and review of literature. Lung 2018; 196: 553-560.

111 Sharma BB, Singh S, Singh V. Hypersensitivity pneumonitis: the dug-well lung. Allergy Asthma Proc 2013; 34: e59-e64.

112 Solana E, Cruz MJ, Romero-Mesones C, et al. Concomitant hypersensitivity pneumonitis and occupational asthma caused by 2 different etiologic agents. Ann Allergy Asthma Immunol 2019; 122: 424-425.

113 Apostolakos MJ, Rossmoore H, Beckett WS. Hypersensitivity pneumonitis from ordinary residential exposures. Environ Health Perspect 2001; 109: 979-981.

114 Utsugi H, Usui Y, Nishihara F, et al. Mycobacterium gordonae-induced humidifier lung. BMC Pulm Med 2015; 15: 108.

115 Yoshikawa S, Tsushima K, Koizumi T, et al. Hypersensitivity pneumonitis induced by spores of Penicillium citrinum in a worker cultivating Enoki mushroom. Intern Med 2006; 45: 537-541.

116 Marchisio VF, Sulotto F, Botta GC, et al. Aerobiological analysis in a salami factory: a possible case of extrinsic allergic alveolitis by Penicillium camembertii. Med Mycol 1999; 37: 285-289.

117 Lee YM, Kim YK, Kim SO, et al. A case of hypersensitivity pneumonitis caused by Penicillium species in a home environment. J Korean Med Sci 2005; 20: 1073-1075.

118 Tanaka H, Sugawara H, Saikai T, et al. Mushroom worker's lung caused by spores of Hypsizigus marmoreus (Bunashimeji): elevated serum surfactant protein D levels. Chest 2000; 118: 1506-1509.

119 Wethasinghe J, Hotu S, Taylor S, et al. Mycobacterium phocaicum and Mycobacterium avium-intracellulare in a patient with hot tub lung. Respirol Case Rep 2015; 3: 19-21.

120 Miyagawa T, Hamagami S, Tanigawa N. Cryptococcus albidus-induced summer-type hypersensitivity pneumonitis. Am J Respir Crit Care Med 2000; 161: 961-966.

121 Gonzalez-Mancebo E, Diez Gomez ML, Pulido Z, et al. Swimming-pool pneumonitis. Allergy 2000; 55: 782-783.

122 Faerden K, Lund MB, Mogens Aalokken T, et al. Hypersensitivity pneumonitis in a cluster of sawmill workers: a 10-year follow-up of exposure, symptoms, and lung function. Int J Occup Environ Health 2014; 20: $167-173$.

123 Millerick-May ML, Mulks MH, Gerlach J, et al. Hypersensitivity pneumonitis and antigen identification--An alternate approach. Respir Med 2016; 112: 97-105.

124 Veillette M, Cormier Y, Israel-Assayaq E, et al. Hypersensitivity pneumonitis in a hardwood processing plant related to heavy mold exposure. J Occup Environ Hyg 2006; 3: 301-307.

125 James PL, Cannon J, Barber CM, et al. Metal worker's lung: spatial association with Mycobacterium avium Thorax 2018; 73: 151-156.

126 Suda T, Chida K, Hayakawa H, et al. Development of bronchus-associated lymphoid tissue in chronic hypersensitivity pneumonitis. Chest 1999; 115: 357-363.

127 Huang WC, Lu YH, Lin ZG, et al. Sauna lung: hypersensitivity pneumonitis due to Exophiala jeanselmei. Respirology 2010; 15: 573-576.

128 Paris C, Herin F, Reboux G, et al. Working with argan cake: a new etiology for hypersensitivity pneumonitis BMC Pulm Med 2015; 15: 18.

129 Otera H, Tada K, Sakurai T, et al. Hypersensitivity pneumonitis associated with inhalation of catechin-rich green tea extracts. Respiration 2011; 82: 388-392.

130 Malmstrom K, Savolainen J, Terho EO. Allergic alveolitis from pine sawdust. Allergy 1999; 54: 532-533.

131 Tripathi A, Grammer LC. Extrinsic allergic alveolitis from a proteolytic enzyme. Ann Allergy Asthma Immunol 2001; 86: 425-427.

132 Barranco P, Moreno-Ancillo A, Munoz Robles ML, et al. Hypersensitivity pneumonitis in a worker exposed to tiger nut dust. J Allergy Clin Immunol 1999; 104: 2 Pt 1, 500-501.

133 van Heemst RC, Sander I, Rooyackers J, et al. Hypersensitivity pneumonitis caused by occupational exposure to phytase. Eur Respir J 2009; 33: 1507-1509.

134 Bertelsen RJ, Svanes O, Madsen AM, et al. Pulmonary illness as a consequence of occupational exposure to shrimp shell powder. Environ Res 2016; 148: 491-499.

135 Mackiewicz B, Skorska C, Dutkiewicz J, et al. Allergic alveolitis due to herb dust exposure. Ann Agric Environ Med 1999; 6: 167-170.

136 Kita T, Nishi K, Fujimura M, et al. A case of hypersensitivity pneumonitis caused by Humicola fuscoatra. Respirology 2003; 8: 95-98.

137 Katayama N, Fujimura M, Yasui M, et al. Hypersensitivity pneumonitis and bronchial asthma attacks caused by environmental fungi. Allergol Int 2008; 57: 277-280. 